\title{
A Step Closer to Local Carbon Calculations: Growth Timescales and Linear Relationships for Sand Forest and Woodland Tree Species in Maputaland, South Africa
}

\author{
Jerome Gaugris ${ }^{1}$, Caroline A. Vasicek ${ }^{2}$ \\ ${ }^{1}$ Centre for Wildlife Management, University of Pretoria, Pretoria, South Africa \\ ${ }^{2}$ Flora Fauna \& Man, Ecological Services Ltd., Tortola, BVI \\ Email: jeromegaugris@florafaunaman.com
}

Received 28 January 2014; revised 4 March 2014; accepted 16 March 2014

Copyright (C) 2014 by authors and Scientific Research Publishing Inc.

This work is licensed under the Creative Commons Attribution International License (CC BY). http://creativecommons.org/licenses/by/4.0/

\section{(c) (i) Open Access}

\begin{abstract}
In Africa, information on time required for plants to develop from seed to mean size and maximum size is scarce. There is also a lack of information regarding accurate relationships between stem diameter, height and canopy dimensions. This type of information is however becoming a real necessity to allow the accurate measurement of carbon stocks and carbon stocks change to qualify for the UNFCCC's REDD+ mechanism. We evaluated these parameters for 22 Sand Forest and woodland tree species of South Africa's Maputaland. Results indicated that it takes approximately 66 and 35 years for current dynamics of Sand Forests and woodlands to occur respectively. Based on diameter and growth rates, larger trees of the forests can be older than 600 years, while large woodland trees can reach ages of 900 years. Our evaluation of linear relationships between stem diameter, height and canopy dimensions showed extremely robust results allowing the use of stem diameter to calculate height and canopy dimensions. The results are of interest for carbon related investigations and reconstructing stands dynamics.
\end{abstract}

\section{Keywords}

Canopy Dimension, Diameter, Height, REDD+

\section{Introduction}

In Maputaland, which has been classified a Biodiversity Hotspot and Centre of Plant Endemism, natural land-

How to cite this paper: Gaugris, J., \& Vasicek, C. A. (2014). A Step Closer to Local Carbon Calculations: Growth Timescales and Linear Relationships for Sand Forest and Woodland Tree Species in Maputaland, South Africa. Open Journal of Forestry, 4, 223-230. http://dx.doi.org/10.4236/ojf.2014.43029 
scape loss appears both within rural areas as well as in formally conserved areas. In rural areas woodlands are cut down and replaced by fields, whilst in conserved areas Sand Forest and woodlands appear to be transforming into grasslands due to the prevalent density of elephants Loxodonta africana, and other large herbivores (Gaugris \& Van Rooyen, 2010a). As in other areas of the country, ecologists in Maputaland are concerned by the rate of degradation of the natural landscape (Matthews et al., 2001; Matthews, 2006; Smith et al., 2006, 2008; Gaugris \& Van Rooyen, 2011) and are looking for solutions on how to conserve it (Gaugris \& Van Rooyen, 2010b). Most of the recent work has concentrated on various forms of Community-Based Natural Resources Management (CBNRM) with the utilisation of wild game featuring as the main driver (Smith et al., 2008). For effective, long term conservation, innovative solutions that add value to the land are needed (Smith et al., 2008).

However, simply setting aside natural forested land, for the purpose of biodiversity conservation for example, has become a potential revenue generator. With South Africa's recent ratification of the agreement on the "Reduced Emissions from Degradation and Deforestation" (REDD+) at the United Nations Framework Convention on Climate Change (UNFCCC) in December 2010 (UNFCCC, 2010), the conservation and sustainable use of forested lands and the enhancement of forest carbon stocks have become three eligible activities for receiving carbon credits and the associated monetary gain (Maniatis \& Mollicone, 2010). As a consequence, it has become crucial for all adhering countries to set up a reliable Measuring, Reporting and Verification system (MRV) as a regulatory, compulsory framework for all aspects related to the international carbon trade under the UNFCCC, including the accurate measurement and description of carbon stocks and carbon emission changes over time (Maniatis \& Mollicone, 2010). Two of the features of this MRV system are to provide: 1) accurate measurements of live above ground biomass of trees/forest, and 2) how it changes over time (Maniatis \& Mollicone, 2010). Biomass calculations need reliable diameter and height estimates in order to provide usable estimates (Khatry Chhetry \& Fowler, 1996; Jayaraman \& Zakrzewski, 2001; Chave et al., 2005). However, no information is available for either of these two parameters for the Maputaland area and calculations need to be done extrapolating from their most comparable European/Asian/American/Central African counterpart species, for which the data are available (Chave et al., 2005). This, of course, is not a truly satisfactory approach.

As a preliminary response to addressing the two points mentioned above, by using published growth rates (Gaugris et al., 2008), we evaluated the time required for 22 trees species to grow to the mean and maximum stem diameter sizes sampled by Gaugris and Van Rooyen (2010a) for the area, thereby giving an indication of the growth time scale which is needed to determine carbon stock in future time. We further determine whether it is possible to reliably use tree diameter as a predictor of height and canopy dimensions for these 22 Maputaland central plain Sand Forest and woodland tree species.

\section{Study Area}

Three study sites are in close proximity to each other, were sampled within the central Maputaland coastal plain. The vegetation consists of woodlands of various densities intermingled with Sand Forest patches (Gaugris \& Van Rooyen, 2008). The region is subtropical, with hot, wet, and humid summers, cool and dry winters, and a mean annual rainfall of $700 \mathrm{~mm}$ (Gaugris et al., 2008). The first site, Tembe Elephant Park (hereafter referred to asTembe, S 27.007049/E 032.432965), was proclaimed in 1983 to protect the Sand Forest vegetation and conserve the region's remaining wildlife. The park covers 30,000 ha and was fully fenced in 1989. The Tshanini Community Conservation Area (2420 ha, 6 km south of Tembe-hereafter referred to as Tshanini, S 27.40511/E 032.373152), which is the second site, represents a section of tribal land set aside by the Manqakulane community in 1992 as a conservation area. Tribal laws protect Tshanini since 1992 and little human utilisation occurs within its boundaries since that date. The third site is the Manqakulane village land (ca. 2500 ha-hereafter referred to as Manqakulane, S 27.153267/E 032.442312) that lies east of Tshaniniand is comprised of the village zone and the portion of land between the village and Tshanini. Tembe, Manqakulane and Tshanini are described in full details in Gaugris and Van Rooyen (2010a).

Growth rates for the species analysed in the present study have been evaluated over a period of 7 years by Gaugris et al. (2008), and a detailed climate data has been presented in this paper.

\section{Methods}

\subsection{Data Collection}

A total of 164, 42 and 48 sample plots were selected through a stratified random sampling approach in the Sand 
Forest and Woodland units of Tembe, Manqakulane and Tshanini respectively. The number of plots was adapted to each of the study area sizes and time available for the study. Plot size varied in length and width depending on the woody plantdensity (i.e. plants with an erect to scrambling growth form and with a ligneous trunk, thus including lianas). In each plot all woody plants with a height of $\geq 0.4 \mathrm{~m}$ and a stem diameter of $\geq 1.0 \mathrm{~cm}$ were identified to the species level and measured. Those with smaller dimensions were only measured for the first half of the plot area. Irrespective of size, the following measurements were taken for each woody plant:

- Stem diameter (D) measured above the basal swelling for most of the plants, and at $100 \mathrm{~cm}$ height above ground for large trees. Depending on the size of the plant, Vernier callipers or measuring tape were used.

- Total height above ground; plants up to $6 \mathrm{~m}$ in height were measured directly with $2 \mathrm{~m}$ high, colour coded, plastic rods that could be assembled to form a rod with the total height of $6 \mathrm{~m}$. For taller trees the height was estimated.

- Maximum extent of the canopy; expressed by the two values D1 and D2, whereby D1 measures the widest/ longest extent of the canopy, whilst D2 quantifies the maximum extension of the canopy in the perpendicular direction to D1. This was done using the same plastic rods as above.

Further detail on the data collection can be viewed in Gaugris and Van Rooyen (2008) and Gaugris and Van Rooyen (2011).

\subsection{Data Analysis}

The analysis was limited to a set of 22 woody species that are representative of woodlands, sand forest and mixed affinity species of the study area and for which the growth rate over a 7-year period was available from a previous study by the authors (Gaugris et al., 2008). Moreover, analysis was limited to the species for which a minimum of 30 individual trees were measured by Gaugris and Van Rooyen (2010a).

The databases representing the sum of all plots surveyed for each of the relevant species were analysed. First, the number of measured plant individuals and their maximum recorded values (stem diameter (D), tree height, canopy diameters D1, D2) are presented along with the mean stem diameter (d) (with standard error) for each of the species. Then, the number of years required for each of the species to grow from an emerging seed of null dimensions to the calculated mean stem diameter and to the maximum recorded stem diameter was extrapolated based on growth rate indications available for the species as provided in (Gaugris et al., 2008). For these two computations, a constant growth rate from seed emergence to adult size was assumed, thus disregarding any static phase that can occur at the seedling or sapling stage while waiting for suitable growth conditions. The overall mean number of years required for Sand Forest and woodlands to grow to their mean and maximum stem diameter dimensions were also established. This was done by calculating the respective mean of the 10 relevant species representative of both the Sand Forest and the woodland vegetation. Lastly, using normal logarithm data transformations and linear regressions, the relationships between stem diameter and total plant height, stem diameter and maximum canopy extent (D1), and stem diameter and perpendicular canopy extension or crown depth (D2) was evaluated. For each relationship, the slope coefficient (a), $\mathrm{R}^{2}$, standard error, F and P values are provided. The software suite GraphPad PRISM 4 (http://www.graphpad.com) was used to perform all calculations.

Gaugris and Van Rooyen (2011) used normal logarithm transformations of the type Ln (Value + 1) in order to conduct regression analysis on stem density over a range of stem diameter size classes. The use of such transformations was based on a review of recommendations expressed by Condit et al. (1998), Lykke (1998), and Niklas et al. (2003) for that type of analysis. These transformations proved remarkably successful at explaining the biological meaning of such regressions through a reliable representation of the data points scatter (high $\mathrm{R}^{2}$ values) and at providing a statistically significant answer (Gaugris \& Van Rooyen, 2011). The further advantage of linear regressions lies in the possibility of expressing a relationship through a simple and easily understood equation. Thus, logarithmic transformations of the type $\ln ($ Diameter +1$)$ and $\ln ($ Height +1$), \ln (\mathrm{D} 1+1), \ln (\mathrm{D} 2+$ 1) were used to standardize the data (Lykke, 1998; Niklas et al., 2003) before performing least square linear regressions on the data. The value of +1 was added because some canopy dimensions were sometimes nil (Lykke, 1998), especially for smaller plants. The linear regressions were performed using diameter as the independent variable and height or canopy dimensions as dependent variables. Because a relationship between stem diameter and height and canopy dimensions starts from the emergence of a seedling of size considered as nil in all these dimensions, the regression was forced through origin and is expressed as $\mathrm{Y}=\mathrm{a}(\mathrm{X})$ where $\mathrm{Y}$ is the dependent 
variable, "a" is the slope coefficient of the regression line, and X the independent variable.

\section{Results}

The overall mean number of years required for the Sand Forest to grow to its overall mean stem diameter and maximum stem diameter dimensions were 66 years (mean $=65.93, \mathrm{SE}=18.58)$ and 335 years $($ mean $=335.17$, $\mathrm{SE}=72.17$ ) respectively. Similarly, for woodlands the overall number of growth years required were 35 years (mean $=35.49, \mathrm{SE}=5.89)$ and 316 years $(315.81, \mathrm{SE}=78.59)$ respectively. Results are expressed in Table 1 and Table 2. With regards to the executed regressions, the data were explained remarkably well by the relationships. The coefficient of determination $\left(\mathrm{R}^{2}\right)$ values were usually $>0.9$ (95\% of species), and all relationships

Table 1. Baseline information on the species investigated and extrapolated number of years required for the species to grow to mean and maximum stem diameter dimensions recorded during surveys.

\begin{tabular}{|c|c|c|c|c|c|c|c|c|c|c|}
\hline \multirow[b]{2}{*}{ Species } & \multirow{2}{*}{$\begin{array}{l}\text { Long term } \\
\text { (7 year) stem } \\
\text { circumference } \\
\text { growth rate } \\
\text { (G) } \\
\text { (mm per year) }\end{array}$} & \multirow{2}{*}{$\begin{array}{l}\text { Number } \\
\text { of } \\
\text { individual } \\
\text { trees } \\
\text { measured } \\
\text { (n) }\end{array}$} & \multicolumn{4}{|c|}{ Maximum dimensions recorded } & \multirow[b]{2}{*}{$\begin{array}{c}\text { Mean } \\
\text { stem } \\
\text { diameter } \\
\text { (d) }\end{array}$} & \multirow[b]{2}{*}{$\begin{array}{c}\text { Standard } \\
\text { error of } \\
\text { mean }\end{array}$} & \multirow{2}{*}{$\begin{array}{l}\text { Extrapolated } \\
\text { number of } \\
\text { years }(\mathrm{yr}) \text { for } \\
\text { growth to mean } \\
\text { stem diameter } \\
(\mathrm{yr}=\mathrm{d} \times \pi / \mathrm{G})\end{array}$} & \multirow{2}{*}{$\begin{array}{l}\text { Extrapolated } \\
\text { number of years } \\
\text { (yr) for growth } \\
\text { to maximum } \\
\text { recorded size } \\
(\mathrm{yr}=\mathrm{D} \times \pi / \mathrm{G})\end{array}$} \\
\hline & & & $\begin{array}{l}\text { Stem } \\
\text { diameter } \\
(\mathrm{D}) \\
(\mathrm{mm})\end{array}$ & $\begin{array}{l}\text { Tree } \\
\text { height } \\
\text { (m) }\end{array}$ & $\begin{array}{c}\text { Max. } \\
\text { canopy } \\
\text { diameter } \\
\text { (D1) (m) }\end{array}$ & $\begin{array}{c}\text { Max. } \\
\text { canopy } \\
\text { diameter } \\
\text { (D2) (m) }\end{array}$ & & & & \\
\hline \multicolumn{11}{|l|}{ Sand Forest species } \\
\hline Brachylaena huillensis & 2.04 & 159 & 450 & 9.0 & 8.0 & 6.5 & 30 & 0.42 & 46 & 693 \\
\hline Cleistanthus schlechteri & 3.69 & 147 & 700 & 15.0 & 16.0 & 14.0 & 177 & 1.17 & 151 & 596 \\
\hline Drypetes arguta & 2.18 & 626 & 250 & 9.0 & 6.0 & 5.0 & 37 & 0.14 & 54 & 360 \\
\hline Hymenocardia ulmoides & 3.48 & 346 & 350 & 12.0 & 8.0 & 6.0 & 47 & 0.33 & 42 & 316 \\
\hline Manilkara discolor & 3.48 & 42 & 700 & 12.0 & 10.0 & 10.0 & 209 & 2.55 & 189 & 632 \\
\hline Psydrax locuples & 4.27 & 315 & 200 & 8.0 & 6.0 & 4.0 & 14 & 0.13 & 11 & 147 \\
\hline Psydrax obovata & 4.88 & 112 & 250 & 8.0 & 8.0 & 6.0 & 70 & 0.56 & 45 & 161 \\
\hline Pteleopsis myrtifolia & 12.20 & 168 & 400 & 13.0 & 15.0 & 10.0 & 117 & 0.78 & 30 & 103 \\
\hline Strychnos henningsii & 3.16 & 77 & 250 & 8.0 & 6.0 & 6.0 & 79 & 0.73 & 78 & 248 \\
\hline Vepris lanceolata & 8.15 & 493 & 250 & 10.0 & 9.0 & 8.0 & 36 & 0.22 & 14 & 96 \\
\hline \multicolumn{11}{|l|}{ Woodland species } \\
\hline Acacia burkei & 7.49 & 446 & 800 & 12.0 & 20.0 & 15.0 & 97 & 0.63 & 41 & 335 \\
\hline Albizia versicolor & 12.01 & 36 & 700 & 12.0 & 17.0 & 15.0 & 124 & 2.54 & 33 & 183 \\
\hline Combretum molle & 6.14 & 226 & 450 & 8.0 & 9.0 & 8.0 & 61 & 0.54 & 31 & 230 \\
\hline Garcinia livingstonei & 26.28 & 40 & 750 & 6.5 & 8.0 & 8.0 & 185 & 2.80 & 22 & 90 \\
\hline Rhus gueinzii & 3.97 & 119 & 250 & 7.0 & 8.0 & 5.0 & 21 & 0.32 & 17 & 198 \\
\hline Sclerocarya birrea & 13.31 & 116 & 900 & 12.0 & 20.0 & 15.0 & 155 & 1.79 & 37 & 212 \\
\hline Spirostachys africana & 2.54 & 319 & 800 & 10.0 & 15.0 & 12.0 & 69 & 0.63 & 85 & 989 \\
\hline Strychnos madagascariensis & 5.65 & 540 & 600 & 7.0 & 8.0 & 8.0 & 54 & 0.35 & 30 & 333 \\
\hline Strychnos spinosa & 4.11 & 385 & 400 & 75.0 & 9.0 & 9.0 & 35 & 0.30 & 26 & 306 \\
\hline Terminalia sericea & 8.91 & 610 & 800 & 10.0 & 58.0 & 14.0 & 97 & 0.51 & 34 & 282 \\
\hline \multicolumn{11}{|l|}{ Mixed affinity species } \\
\hline Afzelia quanzensis & 3.68 & 72 & 820 & 12.0 & 40.0 & 22.0 & 287 & 2.49 & 245 & 700 \\
\hline Dialium schlechteri & 4.74 & 440 & 1000 & 15.0 & 18.0 & 18.0 & 98 & 0.76 & 65 & 662 \\
\hline
\end{tabular}

*From Gaugris and Van Rooyen (2007); \# Based on the assumption that the growth rate is constant from plant emergence onwards with no static periods; Denotes the maximum canopy diameter that is perpendicular to D1. 
Table 2. Relationships between stem diameter and tree height, stem diameter and maximum tree canopy dimension, stem diameter and tree canopy perpendicular to maximum canopy dimension.

\begin{tabular}{|c|c|c|c|c|c|c|c|c|c|c|c|c|}
\hline \multirow{3}{*}{ Species } & \multicolumn{4}{|c|}{ Diameter to height relationship } & \multicolumn{4}{|c|}{ Diameter to canopy D1 relationship } & \multicolumn{4}{|c|}{ Diameter to canopy D2 relationship } \\
\hline & $\begin{array}{l}\text { Diameter } \\
(\mathrm{X}) \text { to } \\
\text { height }(\mathrm{Y}) \\
\text { relationship: } \\
\mathrm{Y}=\mathrm{a}(\mathrm{X})\end{array}$ & $\mathrm{R}^{2}$ & SE & F value & $\begin{array}{c}\text { Diameter } \\
(\mathrm{X}) \text { to } \mathrm{D} 1 \\
(\mathrm{Y}) \\
\text { relationship: } \\
\mathrm{Y}=\mathrm{a}(\mathrm{X})\end{array}$ & $\mathrm{R}^{2}$ & SE & F value & $\begin{array}{c}\text { Diameter } \\
(\mathrm{X}) \text { to } \mathrm{D} 2 \\
(\mathrm{Y}) \\
\text { relationship: } \\
\mathrm{Y}=\mathrm{a}(\mathrm{X})\end{array}$ & $\mathrm{R}^{2}$ & SE & F value \\
\hline & a & & & & a & & & & a & & & \\
\hline \multicolumn{13}{|l|}{ Sand Forest species } \\
\hline Brachylaena huillensis & 0.7679 & 0.9265 & 0.2960 & 1992.0 & 0.5470 & 0.8970 & 0.2588 & 1384.2 & 0.4687 & 0.9131 & 0.2018 & 1670.9 \\
\hline Cleistanthus schlechteri & 0.7022 & 0.9761 & 0.3231 & 5980.0 & 0.6131 & 0.9769 & 0.2775 & 6178.5 & 0.5645 & 0.9838 & 0.2133 & 8872.0 \\
\hline Drypetes arguta & 0.7708 & 0.9490 & 0.2662 & 11635.7 & 0.6226 & 0.9458 & 0.2221 & 10902.1 & 0.5419 & 0.9411 & 0.2021 & 9978.3 \\
\hline Hymenocardia ulmoides & 0.8332 & 0.9352 & 0.3492 & 4980.1 & 0.6308 & 0.9369 & 0.2608 & 5118.9 & 0.5392 & 0.9481 & 0.2010 & 6300.2 \\
\hline Manilkara discolor & 0.6411 & 0.9746 & 0.3136 & 1573.9 & 0.5457 & 0.9678 & 0.3019 & 1231.1 & 0.5117 & 0.9723 & 0.2616 & 1441.8 \\
\hline Psydrax locuples & 0.8644 & 0.9327 & 0.2157 & 4354.6 & 0.7209 & 0.9248 & 0.1908 & 3874.9 & 0.6054 & 0.9194 & 0.1663 & 3595.5 \\
\hline Psydrax obovata & 0.8093 & 0.9607 & 0.3367 & 2716.6 & 0.6152 & 0.9684 & 0.2288 & 3398.6 & 0.5575 & 0.9654 & 0.2173 & 3095.2 \\
\hline Pteleopsis myrtifolia & 0.7334 & 0.9700 & 0.3098 & 5409.4 & 0.6130 & 0.9725 & 0.2478 & 5909.7 & 0.5439 & 0.9744 & 0.2119 & 6363.3 \\
\hline Strychnos henningsii & 0.6732 & 0.9465 & 0.3362 & 1346.6 & 0.5816 & 0.9657 & 0.2304 & 2139.8 & 0.4964 & 0.9573 & 0.2204 & 1704.1 \\
\hline Vepris lanceolata & 0.8550 & 0.9442 & 0.2942 & 8332.7 & 0.6608 & 0.9436 & 0.2285 & 8279.3 & 0.5743 & 0.9364 & 0.2116 & 7293.1 \\
\hline \multicolumn{13}{|l|}{ Woodland species } \\
\hline Acacia burkei & 0.6088 & 0.9682 & 0.2380 & 13578.1 & 0.5905 & 0.9655 & 0.2413 & 12438.8 & 0.5315 & 0.9593 & 0.2366 & 10475.5 \\
\hline Albizia versicolor & 0.4874 & 0.9179 & 0.3958 & 391.6 & 0.5195 & 0.9391 & 0.3595 & 539.4 & 0.4479 & 0.9150 & 0.3708 & 376.9 \\
\hline Combretummolle & 0.6566 & 0.9429 & 0.2829 & 3716.5 & 0.6288 & 0.9581 & 0.2353 & 5148.6 & 0.5334 & 0.9614 & 0.1914 & 5597.1 \\
\hline Garcinia livingstonei & 0.4669 & 0.9839 & 0.1613 & 2395.3 & 0.4747 & 0.9567 & 0.2734 & 862.4 & 0.4162 & 0.9370 & 0.2923 & 579.9 \\
\hline Rhus gueinzii & 0.7498 & 0.9044 & 0.2614 & 1117.0 & 0.7199 & 0.9287 & 0.2139 & 1538.0 & 0.5548 & 0.9206 & 0.1748 & 1367.3 \\
\hline Sclerocarya birrea & 0.5573 & 0.9704 & 0.2422 & 3776.1 & 0.5624 & 0.9601 & 0.2875 & 2791.2 & 0.5088 & 0.9636 & 0.2478 & 3074.7 \\
\hline Spirostachys africana & 0.6814 & 0.9545 & 0.2657 & 6681.2 & 0.6003 & 0.9648 & 0.2050 & 8711.7 & 0.5215 & 0.9666 & 0.1734 & 9193.7 \\
\hline Strychnos madagascariensis & 0.5606 & 0.9414 & 0.2329 & 8660.4 & 0.5764 & 0.9480 & 0.2247 & 9856.0 & 0.5052 & 0.9421 & 0.2084 & 8802.9 \\
\hline Strychnos spinosa & 0.6299 & 0.8691 & 0.3305 & 2550.2 & 0.5554 & 0.9269 & 0.2110 & 4866.8 & 0.4569 & 0.9079 & 0.1968 & 3784.4 \\
\hline Terminalia sericea & 0.5921 & 0.9618 & 0.2526 & 981.1 & 0.5843 & 0.9556 & 0.2694 & 13167.8 & 0.5194 & 0.9543 & 0.2431 & 12783.4 \\
\hline \multicolumn{13}{|l|}{ Mixed affinity species } \\
\hline Afzelia quanzensis & 0.6112 & 0.9726 & 0.3336 & 2529.3 & 0.6306 & 0.9621 & 0.4075 & 1802.7 & 0.5863 & 0.9452 & 0.4597 & 1224.3 \\
\hline Dialium schlechteri & 0.6517 & 0.9334 & 0.3541 & 6159.5 & 0.6144 & 0.9338 & 0.3336 & 6275.7 & 0.5548 & 0.9420 & 0.2808 & 7221.3 \\
\hline
\end{tabular}

For all calculations $P>0.01$.

were highly significant (>0.01), thereby indicating that these equations are reliable tools to determine height and canopy dimensions from the diameter values.

\section{Discussion}

The evaluation of the time required for trees to grow from seedling to mature tree size investigated in Maputaland region indicates that the remaining intact landscapes may have required 300 - 400 years to develop to their 
current physiognomy, while they require at least 66 years to develop to their current level of dynamics in the case of forests, and 35 years in the case of woodlands. These are two significant timeframes that need to be taken into consideration when designing conservation area networks that take into account climate change and social pressure. Thus, the apparently generous 50 year management timeframe (based on estimated life expectancies of up to 300 years) suggested by Gaugris and Van Rooyen (2010b) may even be insufficient to take into account full growth of the dominant landscape tree species. Normally ecologists work on a 20 - 50 years implementation timeframe (Smith \& Leader Williams, 2006) reference which, particularly in the case of sand forest, illustrates how insufficient this is, as a timeline that can be three times longer may be required to regain lost dynamics.

The timelines mentioned here are of further importance in the debate on how Sand Forest evolved, and whether it is a relic vegetation type or a case of stasis while environmental conditions change (Matthews, 2006). Transitions between forests and savannas states have been a regular feature of the African landscape over the past 18,000 years (Schwartz et al., 1996; Van Gemeerden, 2004; Leal, 2004) and today still, a range of situations exists where it is unknown whether savannas will be overrun by forest, or whether forests are retreating, with progress of forest/savanna fronts measured at scales of $50 \mathrm{~m}$ per century (Schwartz et al., 1996). Such dynamics have been proven to range over centuries, and the current "stasis" apparent for Sand Forest (Matthews, 2006) could be considered as normal in light of the indications provided for Sand Forest dynamics timelines in the present study.

In terms of tree heights and canopy dimensions (above ground live biomass), the developed equations proved highly accurate and can be used reliably (high coefficients of determination and highly significant regressions) and quickly to assess some of the elements required for biomass calculations, an aspect that has become crucially important in order to achieve higher tiers in the context of REDD+ (Djomo et al., 2010) through developing results based on local measurements instead of relying on defaults values applied for larger geographical regions of limited applicability or relevance. The high similarity and homogeneity of the Maputaland central plain vegetation (Matthews et al., 2001; Gaugris et al., 2004) indicates that these equations are most probably valid for a significant portion of the Maputaland Centre of Endemism area shared by Mozambique and South Africa. The implications from these equations could, and should now be used within a systematic conservation planning scenario to reliably estimate the potential for carbon sequestration by hardwood and evergreen forests in the region (Smith \& Leader Williams, 2006) and the potential revenue that could be derived by the conservation of these landscape. It is hoped that this work can be of further use to the reliable estimation of above ground biomass in the context of REDD+ for Maputaland, a region that has substantial interest for South Africa, Mozambique and Swaziland and for which so far no species specific indications representing local variability were available (Henry et al., 2011). Moreover, the reliability of the present estimation simplifies considerably the field work requirements, and allows the use of low skilled labour in a reliable way, thereby permitting rural citizen empowerment.

Further uses of these equations are obvious in terms of sustainable utilisation to estimate wood volume or tree biomass that may be harvested from an area, but also for example to reconstruct past stand characteristics (Khatry Chhetry \& Fowler, 1996). This would be the case when for example only tree stumps are left subsequent to harvesting by people, as is often observed in the Maputaland region (Gaugris \& Van Rooyen, 2007). The equations can then become reliable tools to estimate past forest biomass, stock changes, and therefore establish past trends.

\section{Conclusion}

In conclusion, because of the robust nature of the results, the authors believe that the current study results and equations provide a useful, practical, fast, and user friendly tool and represent a satisfactory alternative to direct measuring of numerous, time-consuming and onerous tree parameters. The authors surmise that the results should facilitate certain carbon calculations in Maputaland thereby hopefully contributing to the conservation of some of Maputaland's unique, endemic, and endangered flora. Finally, the present result provides a background to the speed at which vegetation dynamics of the Maputaland region may progress, which should be considered within timeframes of 300 - 400 years.

\section{Acknowledgements}

Sincere thanks are expressed to Sabelo Mthembu who assisted with fieldwork; Ezemvelo Kwa Zulu-Natal Wild- 
life for research facilities use; the University of Pretoria for financial support. This research was supported by the South African National Research Foundation under Grant Number 2053522.

\section{References}

Chave, J., Andalo, C., Brown, S., Cairns, M. A., Chambers, J. Q., Eamus, D., Folster, H., Fromard, F., Higuchi, N., Kira, T., Lescure, J.-P., Nelson, B. W., Ogawa, H., Puig, H. Riera, B., \& Yamakura, T. (2005). Tree Allometry and Improved Estimation of Carbon Stocks and Balance in Tropical Forests. Oecologia, 145, 87-99. http://dx.doi.org/10.1007/s00442-005-0100-X

Condit, R., Sukumar, R., Hubbel, S., \& Foster, R. (1998). Predicting Population Trends from Size Distributions: A Direct Test in a Tropical Tree Community. The American Naturalist, 152, 495-509. http://dx.doi.org/10.1086/286186

Djomo, A. N., Ibrahima, A., Saborowski, J., \& Gravenhorst, G. (2010). Allometric Equations for Biomass Estimations in Cameroon and Pan Moist Tropical Equations Including Biomass Data from Africa. Forest Ecology and Management, 260, 1873-1885. http://dx.doi.org/10.1016/j.foreco.2010.08.034

Gaugris, J. Y., Matthews, W., Van Rooyen, M. W., \& Bothma, J. du P. (2004). The Vegetation of Tshanini Game Reserve and a Comparison with Equivalent Units in the Tembe Elephant Park in Maputaland, South Africa. Koedoe, 4, 9-29.

Gaugris, J. Y., \& Van Rooyen, M. W. (2007). The Structure and Harvesting Potential of the Sand Forest in Tshanini Game Reserve, South Africa. South African Journal of Botany, 73, 611-622. http://dx.doi.org/10.1016/j.sajb.2007.06.004

Gaugris, J. Y., \& Van Rooyen, M. W. (2008). Disturbance-Induced Complexity of Sand Forest in Maputaland, South Africa? South African Journal of Wildlife Research, 38, 171-184. http://dx.doi.org/10.3957/0379-4369-38.2.171

Gaugris, J. Y., Van Rooyen, M. W., \& Bothma, J. du P. (2008). Growth Rate of Selected Woody Species in Northern Maputaland, KwaZulu-Natal, South Africa. South African Journal of Botany, 74, 85-92. http://dx.doi.org/10.1016/j.sajb.2007.09.001

Gaugris, J. Y., \& Van Rooyen, M. W. (2010a). Woody Vegetation Structure in Conserved versus Communal Land in a Biodiversity Hotspot: A Case Study in Maputaland, South Africa. South African Journal of Botany, 76, 289-298. http://dx.doi.org/10.1016/j.sajb.2009.11.007

Gaugris, J. Y., \& Van Rooyen, M. W. (2010b). Evaluating the Adequacy of Reserves in the Tembe-Tshanini Complex: A Case Study in Maputaland, South Africa. Oryx, 76, 399-410. http://dx.doi.org/10.1017/S0030605310000438

Gaugris, J. Y., \& Van Rooyen, M. W. (2011). The Effect of Herbivores and Humans on the Sand Forest Species of Maputaland, Northern KwaZulu-Natal, South Africa. Ecological Research, 26, 365-376.

http://dx.doi.org/10.1007/s11284-010-0791-2

Henry, M., Picard, N., Trotta, C., Manlay, R. J., Valentini, R., Bernoux, M., \& Saint-André, L. (2011). Estimating Tree Biomass of Sub-Saharan African Forests: A Review of Available Allometricequations. Silva Fennica, 45, 477-569. http://dx.doi.org/10.14214/sf.38

Jayaraman, K., \& Zakrzewski, W. T. (2001). Practical Approaches to Calibrating Height-Diameter Relationships for Natural Sugar Maple Stands in Ontario. Forest Ecology and Management, 148, 169-177. http://dx.doi.org/10.1016/S0378-1127(00)00534-X

Khatry Chhetry, D. B. K., \& Fowler, G. W. (1996). Prediction Models for Estimating Total Heights of Trees from Diameter at Breast Height Measurements in Nepal's Lower Temperate Broad-Leaved Forests. Forest Ecology and Management, 84, 177-186. http://dx.doi.org/10.1016/0378-1127(96)03726-7

Leal, M. E. (2004). The African Rain Forest during the Last Glacial Maximum, an Archipelago of Forests in a Sea of Grass. Ph.D. Thesis, Wageningen: University of Wageningen.

Lykke, A. M. (1998). Assessment of Species Composition Change in Savanna Vegetation by Means of Woody Plants’ Size Class Distributions and Local Information. Biodiversity and Conservation, 7, 1261-1275. http://dx.doi.org/10.1023/A:1008877819286

Maniatis, D., \& Mollicone, D. (2010). Options for Sampling and Stratification for National Forest Inventories to Implement REDD+ under the UNFCCC. Carbon Balance and Management, 5, 9. http://www.cbmjournal.com/content/5/1/9 http://dx.doi.org/10.1186/1750-0680-5-9

Matthews, W., Van Wyk, A. E., Van Rooyen, N., \& Botha, G. A. (2001). Vegetation of the Tembe Elephant Park, Maputaland, South Africa. South African Journal of Botany, 67, 573-594.

Matthews, W. (2006). Contributions to the Ecology of Maputaland, Southern Africa, with Emphasis on Sand Forest. Ph.D. Thesis, Pretoria: University of Pretoria.

Niklas, K. J., Midgley, J. J., \& Rand, R. H. (2003). Tree Size Frequency Distributions, Plant Diversity, Age and Community Disturbance. Ecology Letters, 6, 405-411. http://dx.doi.org/10.1046/j.1461-0248.2003.00440.x 
Schwartz, D., De Foresta, H., Mariotti, A., Balesdent, J., Massimba, J. P., \& Girardin, C. (1996). Present Dynamics of the Savanna-Forest Boundary in the Congolese Mayombe: A pedological, Botanical and Isotopic $\left({ }^{13} \mathrm{C}\right.$ and $\left.{ }^{14} \mathrm{C}\right) \mathrm{Study}$. Oecologia, 106, 516-524. http://dx.doi.org/10.1007/BF00329710

Smith, R. J., \& Leader-Williams, N. (2006). The Maputaland Conservation Planning System and Conservation Assessment. Canterbury: Durrell Institute of Conservation and Ecology, University of Kent.

Smith, R. J., Goodman P. S., \& Matthews, W. S. (2006). Systematic Conservation Planning: A Review of Perceived Limitations and an Illustration of the Benefits, Using a Case Study from Maputaland, South Africa. Oryx, 40, 400-410. http://dx.doi.org/10.1017/S0030605306001232

Smith, R. J., Easton, J., Nhancale, B. A., Armstrong, A. J., Culverwell, J., Dlamini, S. D., Goodman, P. S., Loffler, L., Matthews, W. S., Monadjem, A., Mulqueeny, C. M., Ngwenya, P., Ntumi, C. P., Soto, B., \& Leader-Williams, N. (2008). Designing a Transfrontier Conservation Landscape for the Maputaland Centre of Endemism Using Biodiversity, Economic and Threat Data. Biological Conservation, 141, 2127-2138. http://dx.doi.org/10.1016/j.biocon.2008.06.010

UNFCCC (2010). Draft Decision -/Convention of the Parties 16: Outcome of the Work of the Ad Hoc Working Group on Long-Term Cooperative Action under the Convention, C. Policy Approaches and Positive Incentives on Issues Relating to Reducing Emissions from Deforestation and Forest Degradation in Developing Countries; and the Role of Conservation, Sustainable Management of Forests and Enhancement of Forest Carbon Stocks in Developing Countries. http://unfccc.int/files/meetings/cop_16/application/pdf/cop16_lca.pdf

Van Gemeerden, B. S. (2004). Disturbance, Diversity and Distributions in Central African Rain Forest. Ph.D. Thesis, Wageningen: University of Wageningen. http://library.wur.nl/WebQuery/wda/1705771 